Корчан Л. М., Корчан М. І., кандидати ветеринарних наук

Полтавська державна аграрна академія

\title{
ПОРІВНЯННЯ ЕФЕКТИВНОСТІ СПОСОБІВ КУЛЬТИВУВАННЯ І ВИДІЛЕННЯ ЛИЧИНОК СТРОНГІЛЯТ У ФЕКАЛІЯХ КІЗ
}

\section{Рецензент - кандидат ветеринарних наук О. С. Клименко}

Наведена порівняльна оцінка способів культивування і виділення личинок стронгілят шлунково-

кишкового тракту у фекаліях кіз за А. М. Петровим, В. Г. Гагаріним залежно від способу зволоження фекалій та розробленим способом культивування і виділення личинок гельмінтів тварин із використанням системи поліпропіленових стаканів. Най-

більш ефективним, безпечним у санітарному відношенні й економічно вигідним виявився спосіб культивування личинок стронгілят із використанням системи поліпропіленових склянок зі зволоженням фекалій 0,1\% розчином стрептоцииду.

Ключові слова: спосіб культивування, фекалї, личинки, інтенсивність інвазіі, пліснява, гельмінтоларвоскопія.

Постановка проблеми. Для об'єктивності вивчення епізоотичної ситуації, постановки діагнозу, оцінки ефективності протипаразитарних заходів, експериментальних спостережень необхідно використовувати комплексне гельмінтоларвоскопіне дослідження із врахуванням видового складу збудників та інтенсивності інвазії у хворої тварини $[1,5]$.

Кількісне гельмінтоларвоскопічне дослідження, на відміну від якісного, дає можливість відрізняти гельмінтозне захворювання від гельмінтоносійства відповідного виду [1, 2]. Визначення видового складу інвазії дає змогу швидко розробити заходи щодо іï ліквідації й профілактики у майбутньому $[2,6,7]$. Найчастіше гельмінтоларвоскопічні дослідження проводять за стронгілятозів і рабдитадозів, збудників яких диференціюють за морфологічними ознаками їх інвазійних личинок $[2,5]$.

Крім того, не менш важливим є також санітарна безпечність способів. У процесі культивування личинок стронгілят шлунково-кишкового тракту в умовах термостату за певного температурного режиму й вологості на поверхні фекалій досить активно розвиваються різноманітні бактерії й сапрофітні гриби, які можуть затримувати розвиток яєць та личинок і створювати небезпеку для довкілля й дослідника. Тривалий контакт людини з міксоміцетами родин Aspergillus, Penicillium, Alternaria може викликати полінози, бронхіальну астму та інші хвороби.

На сьогодні у лабораторіях ветеринарної медицини найбільш поширеними є методи культивування личинок гельмінтів у тварин за способом А. М. Петрова і В. Г. Гагаріна (1953); Н. А. Акуліна (1965). Виділення личинок у таких випадках проводять за методом Бермана (1917). Проте ці відомі способи культивування личинок гельмінтів є якісними, - рівень інтенсивності інвазії за ними можливо визначити лише за умов незручної й трудомісткої стандартизації, поскільки вони не передбачають використання лічильних камер.

Аналіз основних досліджень і публікацій, у яких започатковано розв'язання проблеми. У літературних джерелах висвітлено чимало модифікацій способу культивування і виділення личинок гельмінтів [5, 7], які недостатньо ефективні, мають окремі недоліки і в лабораторній практиці до цього часу не знайшли необхідного застосування. Дані про порівняння ефективності способів культивування і виділення личинок гельмінтів щодо стронгілятозів у овець і кіз як у зарубіжній, так i у вітчизняній літературі обмежені. Звідси постає питання стосовно вивчення їх ефективності за діагностики стронгілятозів шлунково-кишкового тракту у дрібної рогатої худоби.

Метою даної роботи було порівняння діагностичної та економічної ефективності відомого способу культивування личинок гельмінтів за А. М. Петровим і В. Г. Гагаріним із зволоженням фекалій у першому випадку водою, а у другому - фізіологічним розчином натрію хлориду 3 наступним виділенням личинок за методом Бермана й розробленого нами способу культивування $\mathrm{i}$ виділення личинок гельмінтів тварин.

Матеріал і методи. Дослідження проводили в наукових лабораторіях кафедр терапії і паразитології та ветеринарно-санітарної експертизи Полтавської державної аграрної академії.

Матеріалом для дослідження були проби фекалій від 25 кіз, спонтанно уражених стронгілятами шлунково-кишкового тракту, що належать власникам особистих підсобних господарств м. Полтава. Проби фекалій відбирали індивідуа- 
льно із прямої кишки кіз за допомогою приладу для відбору проб фекалій у дрібної рогатої худоби [3]. Від кожної тварини досліджували проби фекалій у трьох послідовностях.

Інтенсивність стронгілятозної інвазії у кіз визначали за флотаційним способом В. М. Трача; вона становила в середньому $355,49 \pm 9,0$ яєць у грамі фекалій.

Культивування личинок стронгілят шлунковокишкового тракту у кіз проводили за способом А. М. Петрова і В. Г. Гагаріна [2, 6, 7]: у першому випадку зволожуючи проби фекалій водою, а в другому - фізіологічним розчином натрію хлориду з наступним виділенням личинок за методом Бермана $[1,6]$. У третьому випадку проби фекалій культивували і виділяли личинок стронгілят за розробленим нами способом [4].

Для стабільності температурного режиму досліджувані проби фекалій кіз ставили у термостат і витримували за температури $27 \pm 1^{\circ} \mathrm{C}$ протягом 14 діб. Щоденно проби виймали із термостату, злегка зволожували відповідним розчином і проводили їх аерацію протягом 30 хвилин. Раз у три дні фекалії обережно перевертали скляною паличкою.

Результати дослідження. Результати проведених досліджень (табл. 1) свідчать, що за культивування личинок стронгілят шлунковокишкового тракту у кіз за способом А. М. Петрова і В. Г. Гагаріна зі зволоженням проб фекалій водою було виявлено, в середньому, 1038,30 $\pm 26,10$ личинок у 5 г фекалій, із зволоженням проб фекалій фізіологічним розчином натрію хлориду $1225,28 \pm 99,79$ личинок, а за розробленим нами способом культивування і виділення личинок

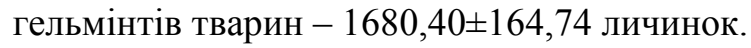

Узагальнюючи результати проведених досліджень можна зазначити, що за ефективністю розроблений нами спосіб кількісного гельмінтоларвоскопічного дослідження тварин перевищував результати відомого методу за А. М. Петро- вим і В. Г. Гагаріним із зволоженням проб фекалій водою у 1,6 разу $(\mathrm{P}<0,05)$, а при зволоженні проб фекалій фізіологічним розчином натрію хлориду у 1,4 разу $(\mathrm{P}<0,01)$. Показники екстенсивності інвазії за розробленим нами способом перевищували метод за А. М. Петровим і В. Г. Гагаріним у середньому на 5,3-6,7\%. Окрім того, показники екстенсивності й інтенсивності інвазії в процесі дослідження послідовних проб фекалій за способом А. М. Петрова і В. Г. Гагаріна значно відрізнялися. Коливання цих показників можна, вочевидь, пояснити розвитком різноманітної мікрофлори, яка затримує розвиток яєць і личинок гельмінтів у фекаліях тварин. У разі мікроскопії проб, отриманих за способом А. М. Петрова i В. Г. Гагаріна, виникали значні труднощі, які пов'язані з підрахунком личинок гельмінтів через значне забруднення суспензії осаду. Крім того даний спосіб культивування личинок потребує трудомістких робіт щодо монтування для кожної проби фекалій апарату Бермана та значних матеріальних затрат. У процесі перенесення проб фекалій зі стаканів у апарат Бермана можлива втрата личинок і забруднення довкілля.

У процесі визначення економічної ефективності способів культивування і виділення личинок стронгілят шлунково-кишкового тракту у кіз нами встановлено, що собівартість способу за А. М. Петровим і В. Г. Гагаріним із зволоженням проб фекалій водою становить 53,11 грн, зі зволоженням проб фекалій фізіологічним розчином натрію хлориду - 53,48 грн, а за розробленим нами способом культивування і виділення личинок гельмінтів тварин - 13,97 грн (табл. 2).

Висновок. За результатами проведених досліджень встановлено, що в разі спонтанного ураженні кіз стронгілятами шлунково-кишкового тракту удосконалений нами спосіб культивування і виділення личинок гельмінтів тварин за ефективністю перевищував результати відомого

\section{1. Порівняльна ефективність способів культивування і виділення личинок стронгілят} у фекаліях кіз

\begin{tabular}{|c|c|c|c|}
\hline Спосіб дослідження & $\begin{array}{c}\text { Кількість } \\
\text { проб }\end{array}$ & $\begin{array}{c}\text { Інтенсивність інвазії, } \\
\text { личинок 3 5 г фекалій }\end{array}$ & $\begin{array}{c}\text { Екстенсивність } \\
\text { інвазії, \% }\end{array}$ \\
\hline $\begin{array}{c}\text { А. М. Петрова і В. Г. Гагаріна } \\
\text { зі зволоженням фекалій водою }\end{array}$ & 75 & $1038,30 \pm 26,10$ & 93,3 \\
\hline $\begin{array}{c}\text { А. М. Петрова і В. Г. Гагаріна } \\
\text { зі зволоженням фекалій 0,85 \% розч. NaCl }\end{array}$ & 75 & $1225,28 \pm 99,79 *$ & 94,7 \\
\hline Розробленим нами & 75 & $1680,40 \pm 164,74 * *$ & 100 \\
\hline
\end{tabular}

Примітка: ступінь вірогідності розробленого до способу А. М. Петрова і В. Г. Гагаріна $* \mathrm{p}<0,05 ; * * \mathrm{p}<0,01$ 


\section{2. Собівартість способів культивування і виділення личинок стронгілят у фекаліях кіз}

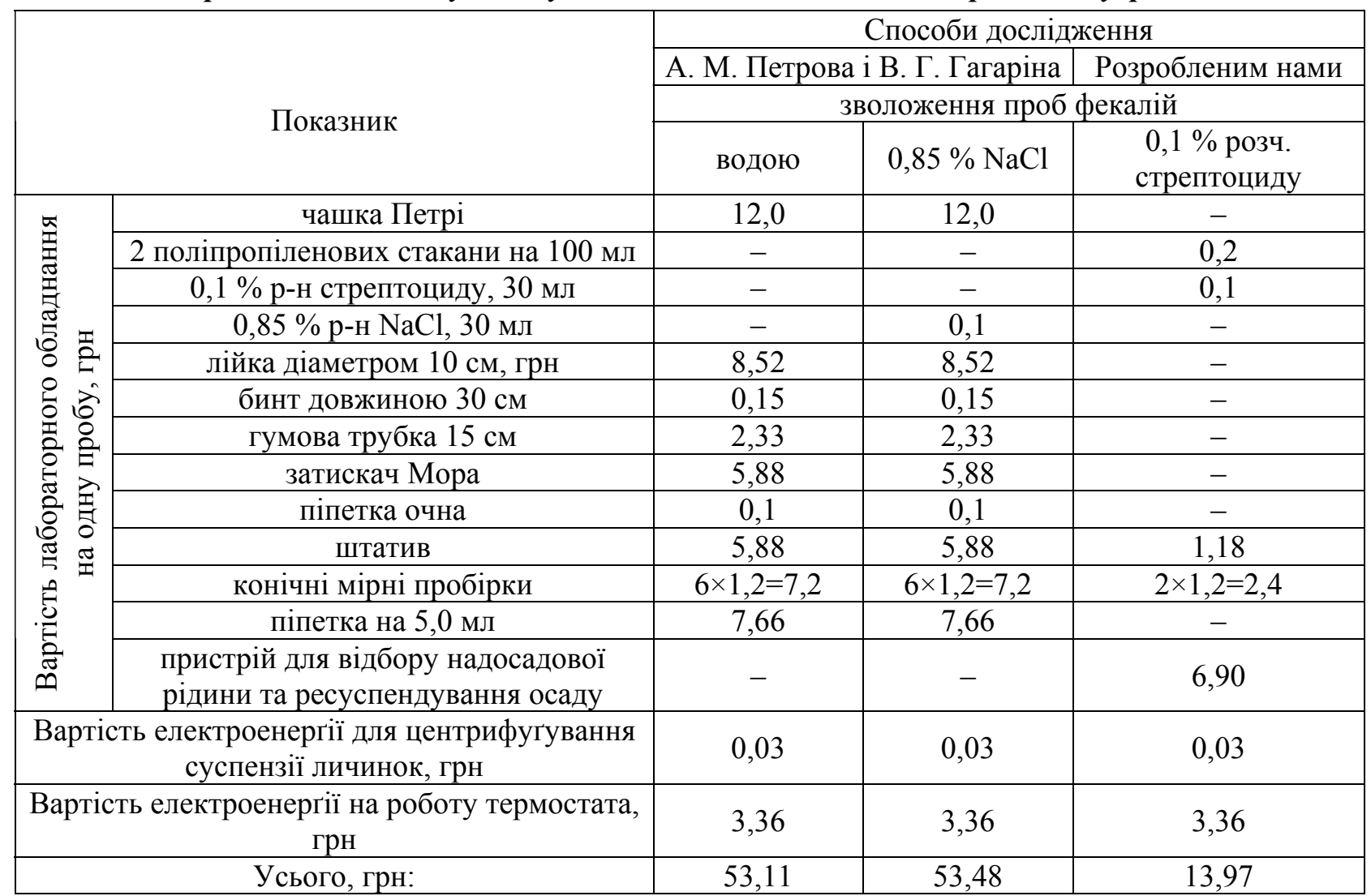

способу за А. М. Петровим і В. Г. Гагаріним у $1,4-1,6$ рази $(\mathrm{P}<0,05)$. Інтенсивність стронгілятозної інвазії за розробленим нами способом культивування і виділення личинок стронгілят у кіз, у середньому, становила 1680,40 $\pm 164,74$ личинок у п’яти грамах фекалій, за методом А. М. Петрова і В. Г. Гагаріна зі зволоженням проб фекалій водою було виявлено, в середньо-

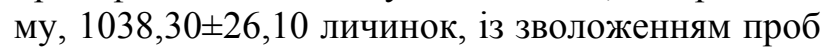
фекалій фізіологічним розчином натрію хлориду

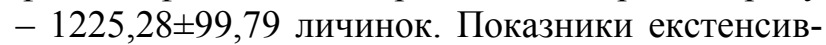

\section{БІБЛІОГРАФІЯ}

1. Галат В. Ф. Методичні вказівки з діагностики гельмінтозів тварин / Галат В. Ф., Березовський А. В., Сорока Н. М. - К. : Ветінформ, 2004. - 54 c.

2. Дахно I. C. Екологічна гельмінтологія. Навчальний посібник / I. С. Дахно, Ю. І. Дахно. - Суми : Козацький вал, Сумська обласна друкарня, 2010. $220 \mathrm{c}$.

3. Корчан Л. М. Прилад для відбору проб фекалій у дрібної рогатої худоби // Ветеринарна медицина України. - 2009. - № 8. - С. 28-29.

4. Патент на корисну модель № 60180 Україна, МПК С12M 3/10 (2006.01) G01N 33/487 (2006.01). Спосіб культивування личинок гельмінтів тварин / Л. М. Корчан, О. Ю. Приходько, Ю. О. Приходько, ності інвазії, визначеної за розробленим методом і методом А. М. Петрова та В. Г. Гагаріна, становили, відповідно, $100 \%$ і 93,3-94,7 \%.

Виділення і культивування личинок строгілят шлунково-кишкового тракту у фекаліях кіз за розробленим способом не потребує складного обладнання й значних затрат часу для дослідження, сприяє санітарній безпеці, підвищенню ефективності лікування тварин, удосконаленню і проведенню основних протипаразитарних заходів.

М. І. Корчан. - № u2010 14576; заявл. 06.12.2010; опубл. 10.06.2011, Бюл. № 11. - 4 c.

5. Пономар C. I. Стандартизація гельімнтокопроларвоскопічних досліджень при стронгілоїдозі // Вісник Білоцерків. державного аграрного університету: Зб. наук. праць. - Біла Церква, 2003. Вип. 23. - Ч. 3. - С. 15-21.

6. Рекомендації щодо гельмінтологічних досліджень тварин / С. І. Пономар, Н. М. Сорока, О. П. Литвиненко [та ін.]. - Біла Церква, 2008. - 78 с.

7. Степанов A. B. Лабораторная диагностика гельминтозов сельскохозяйственных животных тропических стран : Методические указания. - М. : MBA, 1983. $-60 \mathrm{c}$. 